\title{
Persistence of three herbicides in a drip-irrigated banana field'
}

\author{
Lii-Chyuan Liu and Miguel Santiago-Córdova
}

\begin{abstract}
Ametryn, diuron and oxyfluorfen at the recommended rates were applied to a drip-irrigated banana field. Soil samples were collected from treated plots 1, 2, 4 and 8 months after initial application. The persistence of these herbicides in soil was measured on the basis of dry weight production of cucumber plants. The results showed that dry weight of cucumbers was significantly lower in soil sampled 1 month after the diuron treatment. However, there were no significant dry weight reductions when cucumbers were grown on soil sampled 1 month after ametryn and oxyfluorfen treatments. Neither did any dry weight reductions occur when these plants were grown on soil sampled 2, 4 and 8 months after all three herbicide treatments. The order of herbicide persistence in soil is established as diuron $>$ ametryn $>$ oxyfluorfen. The short persistence of these three herbicides in a drip-irrigation banana field is thus confirmed on the basis of results of this study.
\end{abstract}

\section{RESUMEN}

Persistencia de tres herbicidas en un guineal regado por goteo

Los herbicidas ametryn, diuron y oxifluorfen a la dosis recomendada se la aplicaron a un campo de banano regado por gofeo. Las muestras de suelo se recogieron uno, dos, cuatro y ocho meses después de la aplicación inicial. Las muestras recogidas se bioensayaron con pepinillo en el invernadero. La persistencia de estos herbicidas en el suelo se midió a base del peso seco de la planta. Los resultados indican que los pesos se redujeron significativamente cuando crecieron en las muestras de suelo recogidas un mes después del tratamiento con diuron. Sin embargo, no hubo una reducción significativa en peso seco cuando crecieron en las muestras recogidas un mes después de la aplicación de ametryn y oxifluorfen, Tampoco se notaron reducciones significativas en pesos secos del pepinillo cuando crecieron en las muestras de suelo recogidas durante los períodos de 2,4 y 8 meses después de los tratamientos de los tres herbicidas. El orden de la persistencia de estos herbicidas en el suelo se estableció así: diuron > ametryn > oxifluorfen. La corta persistencia de estos herbicidas en un campo de banano regado por goteo se confirmó por los resultados de este estudio.

\section{INTRODUCTION}

Drip irrigation is increasingly used by local farmers to grow plantains and bananas on the south coast of the island. Two frequently used preemergence herbicides, ametryn and oxyfluorfen, are being tried for

'Manuscript submitted to the Editorial Board 22 May 1990.

2Plant Physiologist, Department of Crop Protection.

${ }^{3}$ Research Assistant, Department of Horticulture. 
controlling major weeds encountered in these crops. A general complaint made by certain farmers is that neither herbicide gives an extended period of weed control. It was thought that a constant steady supply of water under drip irrigation might contribute to the short persistence in soil. However, no attempt was made to confirm this assumption. Numerous studies have been carried out in the United States to relate rainfall, flooding and irrigation to herbicide persistence in soil $(2,3,4,10,11,12$, 13). In Puerto Rico, two herbicide persistence studies $(6,5$,$) were con-$ ducted about 20 years ago, long before the wide acceptance of drip irrigation. Consequently, the persistence behavior of our widely used herbicides in soil under drip conditions is largely unknown on plantain and banana plantations. The present experiment was thus conducted in an attempt to determine the persistence of ametryn [N-ethyl- $\mathrm{N}^{\prime}$-(1-methyl)6-(methylthio)-1,3,5-triazine-2,-diamine], diuron [ $\mathrm{N}^{\prime}$-(3,4-dichlorophenyl)$\mathrm{N}, \mathrm{N}$-dimethylurea] and oxyfluorfen [2-chloro-1-(3-ethoxy-4-nitrophenoxy)4-(trifluoromethyl) benzen] in a drip-irrigated Santa Isabel soil.

\section{MATERIALS AND METHODS}

One field experiment and four greenhouse experiments were established at a private farm (Santa Isabel) and the Río Piedras Agricultural Experiment Station. The soil on the private farm is a San Antón clay loam (Cumulic Haplustolls, fine-loamy, mixed, isohyperthermic, $\mathrm{pH} 8.5$ and organic matter $2.8 \%$ ). For the field experiment at the private farm, the suckers of banana cultivar Grant Nain were planted in the Santa Isabel area 10 April 1989. Herbicides ametryn (Evik $80 \mathrm{~W}$ ), diuron (Karmex $80 \mathrm{DF}$ ) and oxyfluorfen (Goal $1.6 \mathrm{E}$ ) at $4.48,3.36 \mathrm{~kg}$ ai/ha and 4.91 $\mathrm{L} / \mathrm{ha}$, respectively, were applied with a portable $\mathrm{CO}_{2}$ sprayer connected to a four-nozzle boom. The spray volume used was $558 \mathrm{~L} / \mathrm{ha}$. The $\mathrm{CO}_{2}$ pressure used for spraying was adjusted to $275 \mathrm{KPa}$. The experimental design was a randomized complete block with four replicates. Individual plot size was $9.1 \times 5.5 \mathrm{~m}\left(50.1 \mathrm{~m}^{2}\right)$ with row spacing at $1.8 \mathrm{~m}$ and distance between plants $1.8 \mathrm{~m}$. A handweeded control was also included in this experiment. Three soil samples were taken from each plot 1,2,4 and 8 months after the initial herbicide application. They were taken to 0-15 $\mathrm{cm}$ depth systematically so that no duplicate samples were taken from the same spot within each plot. The collected soil samples within each plot were composited and air-dried individually. The air-dried soil was then pulverized, ground and stored for bioassay. Weed control data for different herbicides were recorded for the first two months after herbicide application.

The first greenhouse experiment was initiated 19 May 1989 at the Río Piedras Station to bioassay soil samples taken after 1 month. A plastic container measuring $26 \times 23 \times 12 \mathrm{~cm}$ was used to contain the composited soil sample for each replicate. Five seeds of cucumber hybrid Gemini \#7 
were planted in each container 19 May 1989. The cucumber plants were allowed to grow on a greenhouse bench for 5 weeks. Afterwards, they were uprooted, rinsed with tap water and dried in an oven to acquire a constant weight. Dry weight from different herbicide treatments were recorded and subjected to statistical analysis. Using Duncan's Multiple Range Test we compared mean values. The second, third and fourth greenhouse experiments were conducted to bioassay the soil samples collected 2, 4, and 8 months after herbicide application. The same cueumber hybrid was used again in these experiments. The same method of bioassay was used as in the first experiment. After 5 weeks growth in a greenhouse, dry weights of cucumber plants were similarly determined. They were subjected to the same type of statistical analysis.

\section{RESULTS AND DISCUSSION}

Predominant weeds present in the experimental plots were pigweed (Amaranthus dubius Mart), wild poinsettia (Euphorbia heterophylla L.), small spider flower (Cleome gynandra L.), jimsonweed (Datura stramonium L.), jungle rice (Echinochloa colona L. Link.), goose grass (Eleusine indica L.), crabgrass (Digitaria sanguinalis L.) and purple nutsedge (Cyperus rotundus L.). Table 1 shows weed control at 1 and 2 months after the initial herbicide application. All three herbicides gave poor control of the above-mentioned weeds at the end of the first month. By the end of the second month, none of the three herbicides provided any weed control. In a previous study, Liu and Boneta (8) used ametryn at $4.48 \mathrm{~kg}$ ai/ha as a preemergence treatment and obtained nearly 2 months of satisfactory weed control in a non-irrigated plantain field at the Gurabo agricultural substation. The difference in length of weed control provided by the same ametryn at $4.48 \mathrm{~kg}$ ai $/ \mathrm{ha}$ in two different irrigation systems seems to indicate that drip irrigation used in the present study could be one of the contributing factors influencing the length of weed control.

TABLE 1.-Weed contral at 1 and 2 months after herbicide applications in a Santa 1sabel drip-irrigated banana field

\begin{tabular}{lccc}
\hline Treatment & $\begin{array}{c}\text { Rate } \\
\text { Kg ai/ha }\end{array}$ & One month & $\begin{array}{c}\text { Weed control at the end of } \\
\text { Two Months }\end{array}$ \\
\hline & & $\%$ & $\&$ \\
Ametryn & 4.48 & 30 & 0 \\
Diuron & 3.36 & 40 & 0 \\
Oxyfluorfen & 0.94 & 15 & 0 \\
weeded check & - & 95 & 98 \\
\hline
\end{tabular}

'Means represent an average of four replications. 
The persistence of the three herbicides in a drip-ixrigated banana soil can be perceived in the dry weight of cucumber grown in soil sampled 1 , 2, 4 and 8 months after herbicide application (table 2). Dry weight of cucumber plants was significantly lower when these plants grew in soil sampled 1 month after diuron treatment. However, there were no significant dry weight differences when cucumbers were grown in soil sampled 1 month after ametyrn and oxyfluorfen treatments. Neither did any dry weight differences exist when cucumbers were grown in soil sampled 2, 4 and 8 months after ametryn, diuron and oxyfluorfen treatments. On the basis of dry weight of cucumber plants grown in soil sampled 1 month after different herbicide treatments, the relative order of herbicide persistence in soil can thus be established as follows: diuron $>$ ametryn $>$ oxyfluorfen. The short persistence of all three herbicides is confirmed on the basis of the results of our bioassay.

The persistence behavior of the three preemergence herbicides in this study suggests that none of them would persist long enough to provide more then one month of weed control. Consequently, the importance of using post emergence herbicides such as glyphosate and paraquat in plantain and banana fields has to be emphasized. The frequency of paraquat application for weed control in plantain has been studied by Almodóvar (1). He reported that six applications of paraquat at the rate of $2.34 \mathrm{~L} / \mathrm{ha}$ provided the best weed control performance and highest fruit production. The optimum time interval and frequency of glyphosate application for weed control in plantain was determined by Liu and Rodríguez (9). They found that optimum time interval and frequency of glyphosate application during a planting-to-harvesting cycle was three applications, one every 6 weeks, of glyphosate at $1 \%$. However, both Almodovar's and Liu's studies $(1,7,8)$ were conducted in the humid mountains of the plantain growing region. Whether said frequencies of both herbicides for weed control are applicable to the flat land of the south coast under predominant drip-irrigated plantain and banana remains to be determined.

TABLE 2,-Dry weights of cucumber plants grown in soil samples taken at different time periods after herbicide treatments as an indication of herbicide persistence in soil

\begin{tabular}{lccccc}
\hline \multirow{2}{*}{ Treatment } & \multicolumn{5}{c}{ Dry weight of cucumber plants at } \\
& Rate & One Month & Two months & Four months & Eight months \\
\hline Ametryn & $k g$ aitha & $g$ & $g$ & $g$ & $g$ \\
Diuron & 4.48 & $5.10 \mathrm{a}^{1}$ & $5.42 \mathrm{a}$ & $4.53 \mathrm{a}$ & $3.98 \mathrm{a}$ \\
Oxyfluorfen & 3.36 & $1.91 \mathrm{~b}$ & $5.21 \mathrm{a}$ & $4.36 \mathrm{a}$ & $3.91 \mathrm{a}$ \\
Weeded check & 0.94 & $6.01 \mathrm{a}$ & $5.80 \mathrm{a}$ & $4.09 \mathrm{a}$ & $3.77 \mathrm{a}$ \\
\hline
\end{tabular}

'Means followed by the same letter or letters do not differ significantly at the 0.05 probability level. 


\section{LITERATURE CITED}

1. Almodóvar, L. A., 1977. Annual progress on control of weeds in crops of economic value. Agric. Exp. Stn., Univ. P.R.

2. Basham, G., T. L. Lavy, L. R. Oliver and H. D. Scott, 1987. Imazaquin persistence and mobility in three Arkansas soils. Weed Sci. 35: 576-82.

3. Frank, R., 1966. Atrazine carryover in production of sugar beets in Southwestern Ontario. Weeds 14: 82-5.

4. Khalid, H, Akkari, R. E. Frans and T. L. Lavy, 1986. Factors affecting degradation of MSMA in soil. Weed Sci. 34: 781-87.

5. Liu, L. C., H. R. Cibes-Viadé and J. González-Ibáñez, 1970. Persistence of atrazine, ametryn, diuron and prometyrn under greenhouse conditions. J. Agric. Univ. P. R. 54 (4): 631-39.

6. - 1971. Persistence of several herbicides in a soil cropped to sugarcane. J. Agric. Univ. P. R. 55 (2): 147-52.

7. - J. A. Rodríguez-García and Nelson Semidey-Laracuente, 1981. Glyphosate for weed control in plantains. J. Agric. Univ. P. R. 65 (4): 317-25.

8. — and E. G. Boneta-Garcia, 1982. Oxyfluorfen for weed control in coffee and plantain. Proc. 18th. annual meeting of Caribbean Food Crops Soc. 215-20.

9. — and J. A. Rodríguez-García, 1988. Optimum time interval and frequeney of glyphosate application for weed control in plantain. J. Agric. Univ. P. R. 72 (2): 297-300.

10. Roeth, F. W., T. L. Lavy and O. C. Burnside, 1969. Atrazine degradation in two soil profiles. Weed Sci. 17: 202-05.

11. Savage, K. E., 1978. Persistence of several dinitroaniline herbicides as affected by soil moisture. Weed Sci. 26: 465-71.

12. Scrifres, C. J., R. R. Hahn, J. Diaz-Colón and M. G. Merkle, 1971. Picloram persistence in semiarid rangeland soils and water. Weed Sci: $381-84$.

13. Switzer, C. M. and W. E. Kauser, 1960. Effectiveness and persistence of certain herbicides in soil. Proc. Northeast. Weed Control Conf. 24: 59-63. 